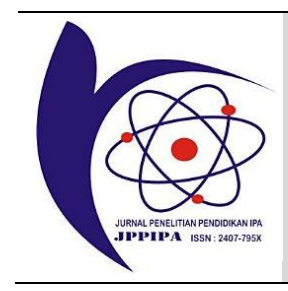

\title{
The Effect of PBL Hybrid Learning on the Higher Order Thinking Skills of Seventh Grade Students in Global Warming and Their Environmental Care Attitudes
}

\author{
Sio Tuti Gultom ${ }^{1}$, Parsaoran Siahaan ${ }^{1}$, Andi Suhandi ${ }^{1}$ \\ ${ }^{1}$ Department of Natural Sciences Education, Universitas Pendidikan Indonesia, Bandung, Indonesia \\ DOI: 10.29303/jppipa.v7iSpecialIssue.1012
}

\section{Article Info}

Received: October 1st, 2021

Revised: December 9th, 2021

Accepted: December 15 1 th 2021

\begin{abstract}
This study aimed to investigate the effect of problem-based learning (PBL) hybrid learning on the higher order thinking skills (HOTS) of seventh grade students in global warming and their environmental care attitudes. The study was conducted using a quasiexperimental design. The participants of the study were 68 students, divided into two groups: one an experimental group $(n=34)$ and the other a control group $(n=34)$. HOTS test (15 multiple choices) and questionnaire (hands on activity) were designed to confirm the study's validity and reliability. SPSS was used to analyze the data. The finding revealed that there were statistically significant differences between the experimental and the control group. The results of post-test data processing (One-Way ANOVA with $\alpha=0.05$ ) show that $\mathrm{HO}$ is rejected and Ha is accepted. This shows that there is a significant effect of PBL hybrid learning on the higher order thinking skills of seventh grade students in global warming and their environmental care attitudes. The study is recommended to use in Indonesia's education system after covid-19 pandemic end to increase education quality. This study showed increasing student's environmental care awareness attitudes.
\end{abstract}

Keywords: PBL; hybrid learning; HOTS; global warming; attitudes

Citation: Gultom, S. T., Siahaan, P., \& Suhandi, A. (2021). The Effect of PBL Hybrid Learning on the Higher Order Thinking Skills of Seventh Grade Students in Global Warming and Their Environmental Care Attitudes. Jurnal Penelitian Pendidikan IPA, 7(SpecialIssue), 272-280. https://doi.org/10.29303/ippipa.v7iSpecialIssue.1012

\section{Introduction}

Currently, the world is moving towards the era of society 5.0. Society 5.0 is a human-centered and technology-based society concept developed by the Japanese government. This concept was born as a development of the 4.0 industrial revolution which is considered to have the potential to degrade the role of humans. It will be an innovation that will surely solve the problems we face in the future. In this new ultrasmart society, everything will be connected via IoT technology and all technology will be integrated, dramatically to improve the quality of life. The Industrial Revolution 4.0 is a strategic initiative introduced by the German government with the aim of transforming the manufacturing industry through digitalization and exploitation of the new technology's potential (Rojko, 2017). Therefore, in terms of learning, educators need to understand the technological developments and changes in learning methods along with technological advances that are currently developing (Sukartono, 2018; The Government of Japan, 2020; Sholihin, 2019; The Government of Japan, 2020; Cabinet Office of Japan, 2019). Society 5.0 has the following characteristics: (1) use full information and communication technology; (2) is centered on community; (3) people participation; (4) has common values: sustainability, inclusive, effective, and intelligence power; and (5) development of economic disruption (Salgues, 2020)

In facing the era of society 5.0, the world of education plays an important role in improving the quality of human resources. Students must have the right basic character to face this era. The combination of

\footnotetext{
*Email: siotuti1@gmail.com
} 
the application of technology and high-order thinking skills must be done to prepare future generations. One of the lessons that support students to improve higher order thinking skills is a problem-based learning model.

Problem Based Learning (PBL) is one of the important learning models for teaching organizations. Barrows first put forward the PBL teaching model in 1969. The theoretical basis of the PBL teaching model is constructivist teaching theory. This model takes students as the center, gives students the actual problem situation, asks students to actively participate in analyzing problems, identifying relevant facts, and building new knowledge, solving problems on a small team scale, to improve their critical thinking skills, which also known as the best think tank (Nelson, 2008; Zhi, 2009; Chen, 2013). The PBL teaching model can be divided into five main steps: question-analysis-problem solving-result reporting-reflection and evaluation (Song, \& Cheng, 2015). The teaching of PBL model emphasizes students' autonomous construction of knowledge, puts forward hypotheses, and finding solutions, namely a way of learning that is conducive to student autonomous learning and initiative development, and at the same time, helps foster a spirit of student collaboration and innovation (Ren, 2015). The PBL model recommends that students learn, discuss and work together to solve problems through independent study, foster students' independent learning abilities, develop students' critical thinking skills, which are characterized by autonomy, openness and cooperation (Lei, 2011).

Currently, technology-based learning is a basic thing so that the learning process can run optimally. The Covid-19 pandemic makes learning based on e-learning because it does not allow face-to-face learning. Learning that was previously only done offline, is now done online. Teachers, students, and parents are required to be technology literate to be able to carry out learning well. It is proven that e-learning-based education is a need for future education. E-learning has become a popular approach to effective learning within the wider academic community. One consequence is a shift in focus in education, from teaching itself to student learning and skills (Kerzic, et al, 2018). E-learning has become a popular effective learning approach in the wider academic community due to the extensive use of web systems in learning. There are a range of benefits of technology-enabled learning, or e-learning. It is largely flexible, allowing learning to occur at a distance, at a time and pace according to student needs (Allan, et al, 2005; Kimathi, et al, 2019). Point out that updating electronic content is easier than updating printed materials: E-learning technology allows educators to review their content quickly and easily (Suresh, 2018). E- learning began in the 1980s and 1990s as computerbased courses provided on standalone disks.

In the late 1990s, such educational courses were then hosted on internal networks, and after that they were incorporated into the learning management system (LMS) in the late 1990s (Abdullah, et al, 2016; Hubackova, 2015). E-learning now refers to anything offered, enabled, or mediated by electronic technology for a clear learning purpose. With the advent of smartphones and tablets and other devices, e-learning has rapidly grown in popularity in various countries due to the diversity of its social and economic standards and the increasing demand for education (Sekhon, et al, 2014). E-learning is effective because it eliminates distance and subsequent changes. This term now includes stand-alone computer-based training, online or web-based learning, and learning that is mediated by mobile, tablet, and other devices (Aristovnik, et al., 2017).

E-learning is a comprehensive term that describes learning that is carried out on computers, usually connected to a network, providing opportunities for students to learn anytime, anywhere (Aleksander, et al, 2007; Oye, et al, 2010). E-learning also includes learnerstudent interaction, as might occur in an online learning community. Hybrid learning has been shown to improve student learning's outcomes (Saritepeci \& Cakir, 2015; Al-Hariri, et al, 2017). On the other hand, some researchers consider e-learning in simple terms as a form of training to learn from each other and communicate with computers, networks or other electronic sources (Lin, et al, 2017; Roffe, 2002; Schank, 2002; Sambrook, 2003).

Furthermore, various studies have shown the benefits and advantages of applying e-learning technology to schools. Some of them are: e-learning is flexible when considering the time and place of study as a problem; increase the effectiveness of knowledge through easy access to a wide range of information; it is cost-effective because students are not required to travel; it takes into account individual differences among students; and the use of e-learning enables selfimprovement (Algahtani, 2011; Marc, 2002; Umek, et al, 2015).

High Order Thinking Skills is a thinking process of students in higher cognitive level developed from various concepts and methods cognitive and learning taxonomies such as problem-solving methods, taxonomy bloom, and the taxonomy of learning, teaching, and assessment (Saputra, 2016). High order thinking skills include problem solving abilities, creative thinking skills, critical thinking, argumentative skills, and abilities make decisions. High order thinking skills are included thinking critically, logically, reflective, metacognitive, and creative (King, 2011). High order 
thinking students will be able to distinguishing ideas or ideas clearly, arguing well, capable solve problems, be able to construct explanations, be able to hypothesize and understand complex things more clearly. The ability to think critically is one of the skills that students must have, because through the ability to think critically, it is easier for them to understand concepts and solve problems on their own (Tresnawati, 2017). High order thinking skills will occur when someone associates new information with information that has been stored in his memory and linked it and rearranging and developing the information to achieve a goal or find a solution to a situation that is difficult to solve. The main purpose of high order thinking skills is how to improve thinking skills of students at a higher level, especially those related to with the ability to think critically in accepting various types information, think creatively in solving a problem using knowledge and make decisions in situations that complex (Saputra, 2016). The concept of high order thinking skills is based on some opinions, as can be seen in Table 1 (Krulik, et al, 1999) Krathwohl, 2002; Anderson, et al, 2001; Kusuma, et al, 2017).

Table 1. Basic Concept of High Order Thinking Skills

\begin{tabular}{llll}
\hline Problem Solving Krulik \& & Taxonomy Bloom's & Bloom's Taxonomy Ander's & High Order Thinking Skills \\
Rudnick (1998) & Cognitive Original (1956) & Revision \& Krathwohl (2001) & - Critical Thinking \\
\hline - Recall & - Knowledge & - Remember & - Creative Thinking \\
- Basic & - Comprehense & - Understand & - Problem Solving \\
- Critical & - Application & - Apply & - Decision Making \\
- Creative & - Analysis & - Analyze & \\
& - Synthesis & - Evaluate & \\
& - Evaluation & - Create & \\
\hline
\end{tabular}

Problem Solving is a process, means that each individual uses the knowledge obtained, skills, understanding which are then used in new situations. Saprudin, et al. (2010) explained that learning concepts and solving various problems in life, especially those related to science, requires generic science skills. The process starts by comparing and concluding then students must combine what has been learned and applies it to new situations. Breaking pattern problems are described in different steps can be taught to students, namely, (1) reading a problem, (2) developing information, (3) choosing strategies, (4) solving problems, and (5) recheck and expand (Krulik, et al, 1999).

As seen in the table above, Bloom divides the cognitive domain into six levels thinking, namely, (1) knowledge or knowledge about recalling information which has been learned, (2) comprehension or understand the meaning of the material, (3) application, using knowledge in new and unfamiliar situations have experienced before or apply rules or principles, (4) analysis, identify and understand parts of the material or the whole material, (5) synthesis, combining elements to form a new whole, and (6) evaluation, examining or judging carefully based on several criteria. The revision of the bloom taxonomy by Anderson and Krathwohl is more focused on how the cognitive domain is livelier and more applicable to educators and learning practices that are expected to help educators in processing and formulate learning objectives and an efficient assessment strategy. The three concepts in on which to become the basis of high order thinking skills refers to the activity of analyzing, evaluate, create knowledge that is adapted to the conceptual, procedural and metacognitive.

According to Krathwohl (2002) in A revision of Bloom's Taxonomy, states that indicators to measure higher order thinking skills includes analyzing (C4), namely the ability to separate concepts into several groups components and relate to each other to gain an understanding of concept as a whole, evaluating (C5), namely the ability to determine the degree of something based on certain norms, criteria or standards, and creating (C6), namely ability combine elements into a new form that is whole and broad, or make something original (Krathwohl, 2002; Anderson, et al, 2001. Based on the results of previous research on the advantages of PBL and e-learning learning, the PBL hybrid learning concept will improve students' higher-order thinking skills in schools where the research is conducted in particular and schools in Indonesia in general.

The environment has an important role to support human life in achieving a better quality of life. Along with the times, the function of the environment is increasingly threatened. Currently there is a global environmental crisis, among others, forest destruction, pollution (land, water, air), climate change, biodiversity extinction, loss of energy resources and other environmental damage (Ministry of Environment, 2014). All the damage that occurs is largely due to human activities that utilize nature without calculation. Only by changing human attitudes and behavior can reduce these environmental problems (Norris, et al, 2016). One of the strategic and sustainable steps that can be taken to 
overcome environmental problems that occur is through education (Muhammad, 2013). Education is the most appropriate vehicle for internalizing values and transforming beliefs, knowledge and skills. Environment education is an effective way to understand environmental management, problems and protection (Pane, et al, 2015).

Environmental education objectives are: 1) Build awareness, which gives encouragement to each individual to gain awareness and sensitivity to the environment and the problem; 2) Increased knowledge, which is helping each individual to gain a variety of experiences and basic understanding of the environment and the problem; 3) Forming attitudes, namely helping each individual to obtain a set of values and abilities to get the right choices and develop feelings that are sensitive to the environment and provide motivation to participate actively in the improvement and protection of the environment; 4) Increase participation, which provides motivation for each individual to actively participate in solving environmental problems; and 5) As an evaluation material that is encouraging individuals to have the ability to evaluate environmental knowledge in terms of ecological, social, economic and other educational factors (Adisendjaja, 2008).

The development of environment education learning through formal education has become the main strategy of the Adiwiyata program. The Adiwiyata Program is a caring and cultured school environment program aimed at realizing responsible school members through good school governance to support sustainable development (Ministry of Environment, 2014). Through environmental education at Adiwiyata School, it is hoped that it will increase the students' environmental awareness attitude (Iswari, et al, 2017). The attitude of caring for the environment is a feeling that a person has to improve and manage the environment properly and beneficially, so that it can be enjoyed continuously without damaging the situation, helping to preserve and preserve it so that there are sustainable benefits (Ministry of Environment, 2014).

The attitude of student is important to know, because student is psychologically at the stage of adolescent development (adolescent) where their opinions are important to study. Changes in attitudes and behavior in someone who is at the adolescent stage, is an important sign for long-term social change (Kuhlemeier, et al, 1999; Febrianawaty, et al, 2016). The understanding given about the environment is expected to emerge awareness for responsible learning, and be positive about the environment. Furthermore, these teenagers will become leaders and make policies in maintaining and preserving the environment (Lake, 2010). The role of Environmental Management towards environmental care attitude has been carried out which states that Environmental Management has formed 99\% good environmental care attitude among students (Pane, et al, 2015; Adisendjaja, 2008). States that if the environmental attitudes of students in Adiwiyata school are still low, it can be caused by an error in understanding the concept of protecting the environment properly (Adisendjaja, 2008). The basic concept of forming an attitude of caring for the environment consists of institutional factors and school management, students' concept knowledge, environmental factors, and educational strategies. Good environmental care attitude is not always influenced by the level of knowledge (Pane, et al, 2015).

\section{Method}

\section{Research design}

A quasi-experimental approach was used because of its suitability to the research objectives and its ability to achieve its objectives using post-achievement tests for the experimental and control groups. Figure 1 illustrates the experimental design of the study: In the control group, students were taught the topic of unit 3 (global warming) from a 7 th grade science textbook using conventional learning. The experimental group was taught the same material using problem-based learning hybrid learning. Materials taught during four meetings in the second semester of the 2020/2021 school year. The teaching topics in the units taught during the study are detailed in Table 2.

\section{Research participants}

The sample consisted of 68 seventh grade students of SMP Negeri 1 Simanindo, Samosir district, North Sumatra province which were divided into two groups: the experimental group consisted of 34 students and the control group consisted of 34 students.

\section{Research variable}

The independent variables are two teaching methods: (1) Problem-based learning model hybrid learning conventional method; (2) Pre-test (before intervention); and (3) Post-test (after intervention). Dependent variable, Higher order thinking skills (HOTS) of students of study research were measured on two occasions (pre-test \& post-test) and responses from the experimental group on environmental care attitudes.

Table 2. The teaching topics in the Global Warming

\begin{tabular}{lll}
\hline Chapter & Topics & Page \\
\hline Global Warming & - Definition of global & -200 \\
& Warming & \\
& - Water pollution & -202 \\
& - Air pollution & -209 \\
\hline
\end{tabular}




\section{Research tools}

Research tools that come from the subject of the researcher's own design, and reviews of previous research and literature related to the researchers' research are an important part in preparing learning materials on computers with the topic of global warming that will be applied to hybrid learning activities while teaching in experimental classes.

\section{1) Educational material}

Teachers are an important part in preparing learning materials on computers on the topic of global warming which will be applied to hybrid learning activities when teaching in experimental classes.

Online science learning will be complemented by using an online learning platform, namely, ms teams. This application can be downloaded for free on the Microsoft website. The platform for online learning that will be used by researchers is open source and free. The platform contains learning content about global warming as the main topic and sub-topics on water, soil and water pollution. This learning material will be delivered during face-to-face learning. When delivering learning materials in class, teachers can use power points for presentations, learning questions, quizzes, animations, learning videos that are relevant and can be uploaded on the platform.

Students can access re-learning videos anywhere and anytime. Students can work on questions and quizzes available on the platform and can discuss again with the teacher when learning in the classroom Researchers interact with students through discussion rooms available on the platform related to global warming materials.

Global warming content to be used on the platform is prepared with the following conditions: (1) Recall knowledge by learning; (2) Adjusting to the learning objectives; (3) The teacher explains the learning activities on the platform; (4) Through hybrid learning will require students to learn independently while studying through the platform that has been provided; (5) This will build teacher-student interaction and build student motivation to learn independently; (6) on the platform, there are student activity sheets when working on questions and quizzes.

\section{2) HOTS's test}

Researchers prepared an achievement test to measure the effectiveness of hybrid learning in improving students' science learning outcomes. The test in its final form consists of 15 multiple choices. Each item of the question is given one value for the correct answer and zero for the wrong answer. The maximum test score is 15 and the test time is 45 minutes.

\section{a) Validity HOTS's test}

The research tool confirmed the virtual validity method to test by presenting it in its initial form with a behavioral goal list, to four university lecturers, all holders of doctoral and master's degrees in curriculum and methods of teaching science, and technology education. The content has been adjusted according to their recommendations.

\section{b) Reliabilitas HOTS's test}

The researchers verified the reliability of the higher order thinking skills (HOTS) test using the testretest method. The test was applied to a sample not included in the study sample, and two weeks after the test was reapplied to the same sample of seventh-grade students. After that, the file Pearson correlation coefficient between the two applications is calculated. A total reliability coefficient of 0.85 was considered appropriate for the purposes of this study.

\section{3) Questionnaire (environmental care attitudes)}

A questionnaire was designed and used to collect data from 34 students from the experimental group about their attitudes towards environmental care attitudes. It consists of 35 items that focus on research purposes. Researchers used a closed-statement Likert scale for responses to questionnaire items using google form. To test the validity and reliability, questionnaires were administered to experts from various universities, who then provided written feedback, in response to which the researcher modified several items to meet the research objectives. The reliability of the questionnaire was also determined using Cronbach's Alpha. The value is 0.89, which indicates a high level of internal consistency. A five-dimensional Likert scale was adopted as follows: very high (5), high (4), moderate (3), small (2) and very little (1). Figure 2. is the format for the Google Foms Questionnaire on caring for the environment.

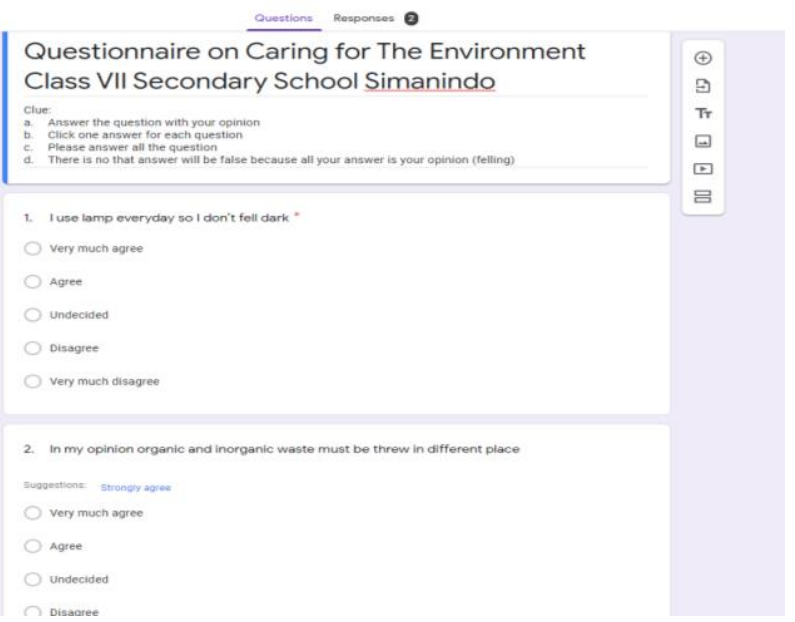

Figure 2. Google Forms Questionnaire on caring for the environment 
Pretest

To compare the two groups in the study in the HOTS, the researcher used a t-test to compare the results of the two groups in an initial test on the topic of a science textbook unit, before applying mixed learning. The results are shown in Tables 3 . and 4 .

Table 3. Means and standard deviations of pre-test scores for two groups

\begin{tabular}{llllll}
\hline No & Class & $\mathrm{N}$ & Mean & Std. Deviation & Std. Error Mean \\
\hline 1 & Experimental & 34.000 & 48.823 & 13.801 & 2.366 \\
2 & Control & 34.000 & 48.628 & 9.783 & 1.677 \\
\hline
\end{tabular}

Table 4. T-test results of pre-test between the experimental and the control groups

\begin{tabular}{llllllll}
\hline & $\mathrm{F}$ & Sig. & $\mathrm{t}$ & $\mathrm{df}$ & Sig. (2-tailed) & Mean Difference & Std. Error Difference \\
\hline Equal variances assumed & 1.823 & 0.182 & 0.067 & 66.000 & 0.947 & 0.195 & 2.901 \\
Equal variances not assumed & & & 0.067 & 59.480 & 0.947 & 0.195 & 2.901 \\
\hline
\end{tabular}

*) Statistically significant at (p $0.05 \geq$ )

As shown in Table 4 . because the $\mathrm{p}$ obtained (0.947) is greater than 0.05 , the test is not significant at the 0.05 level which indicates that there is no significant difference between the two study groups (experimental group and control group). This revealed that the experimental group and the control group were equal before the study could be applied.

\section{Statistical treatment}

Researchers used the SPSS program to answer the research questions. By calculating the arithmetic mean and standard deviation, an independent sample t-test was used to statistically measure the difference in mean between the experimental group and the control group in the post-test results. In addition, paired sample t-test was used to compare pre-application and postapplication experimental group scores for the mixed learning attitude scale. One-way ANOVA test was also used to analyze the pre-test and post-test of the experimental class.

\section{Result and Discussion}

To obtain the analysis results whether there is a significant effect of PBL hybrid learning on students' HOTS, the null hypothesis is tested, there is no statistically significant difference between the mean scores of the experimental group, which uses PBL hybrid learning in the study, and the mean scores students in the control group, who used conventional learning, in the post-achievement test. To verify the hypothesis, the difference between the mean student scores in the experimental group and the control group in post-test was calculated using t-test for two independent samples. That the results are shown in Table 5. and Table 6.

Table 5. Means and standard deviations of post-test scores for two groups

\begin{tabular}{llllll}
\hline No & Class & $\mathrm{N}$ & Mean & Std. Deviation & Std. Error Mean \\
\hline 1 & Experimental & 34 & 73.921 & 10.165 & 1.743 \\
\hline 2 & Control & 34 & 60.980 & 10.526 & 1.805 \\
\hline
\end{tabular}

Table 6. T-test results of pre-test between the experimental and the control groups

\begin{tabular}{lllllllll}
\hline & $\mathrm{F}$ & $\mathrm{Sig}$. & $\mathrm{t}$ & $\mathrm{df}$ & Sig. 2-tailed) & Mean Difference & $\begin{array}{l}\text { Std. Error } \\
\text { Difference }\end{array}$ \\
\hline Equal variances assumed & 0.064 & 0.801 & 5.156 & 66.000 & 0.000 & 12.940 & 2.509 \\
Equal variances not assumed & & & 5.156 & 65.920 & 0.000 & 12.941 & 2.509 \\
\hline
\end{tabular}

*) Statistically significant at (p $0.05 \geq$ )

As shown in Table 6, because the p-value (0.000)

is smaller of 0.05 , this means that there is a significant difference in the significance of 0.05 level, which indicates that there is a significant difference between both groups of learners with regard to students' HOTS on science topics covered after 4 weeks. It means null hypothesis is rejected. Based on the test results, it can be concluded that teaches global warming topic units in science textbooks through PBL hybrid learning has a positive effect on students'

\section{HOTS scores.}

Based on the results shown in Table 7 . it is seen that there is a significant difference $(t$ (67) $24.556 \mathrm{p}<.05)$ between the experimental mean of post-application group students (6137250) and their pre-application average (48.82).

Table 7. Comparison of experimental group students' pre-application and post application scores of the PBL hybrid learning the paired samples t-test 


\begin{tabular}{llccc}
\hline & $\mathrm{t}$ & $\mathrm{df}$ & Sig. (2-tailed) & Mean Difference \\
\hline Post test & 29.001 & 67 & 0.000 & 61.372 \\
Pretest & 24.556 & 67 & 0.000 & 48.820 \\
\hline
\end{tabular}

*) Statistically significant at (p $0.05 \geq$ )

Table 8. One-way ANOVA test for variable student HOTS in science subject

\begin{tabular}{lllll}
\hline No & & $\mathrm{df}$ & $\mathrm{F}$ & Sig. \\
\hline 1 & Between Groups & 1.000 & 72.891 & 0.000 \\
2 & Within Groups & 66.000 & & \\
3 & Total & 67.000 & & \\
\hline
\end{tabular}

*) Statistically significant at (p $0.05 \geq)$

This means that the null hypothesis is rejected. Based on these findings, it is certain that the experimental group developed more positive attitudes towards the use of PBL hybrid learning in science after they experienced the application of the model. Our results in Table 8 imply that the environmental care and attitude of the experimental group students differed according to their HOTS ability scores.

\section{Conclusion}

The results of the analysis carried out in this study show that the application of the PBL Hybrid Learning model has a positive impact on Higher Order Thinking Skills of Seventh Grade Students. There were statistically significant differences between the experimental group and the control group, supporting the experimental group, which was taught using PBL hybrid learning. In addition, the research results show that Environmental Care Attitudes are increasing along with the implementation of this research.

\section{Acknowledgements}

Thank you to God Almighty, who has given me the health to complete this research and I would like to thank Parsaoran Siahaan, Prof. Dr. Andi Suhandi, Rafles Sinaga who have given me the spirit to motivate me and I also love my supervisor who has helped me finish this research and not forgetting I thank my friends who always give help in my research.

\section{References}

Abdullah, F., Ward, R. (2016). Developing a general extended technology acceptance model for Elearning (GETAMEL) by analysing commonly used external factors, Comput Hum. Behav, 56. 238256. https://doi.org/10.1016/i.chb.2015.11.036

Adisendjaja, Y. (2008). Environmental Education Learning, Learning fromNature and experience. UPI. Bandung.
Aleksander, A., Tomazevic, N., Kerzic, D., Umek, L. (2017). The impact of demographic factors on selected aspects of e-learning in higher education Int. J. Inf. Learn. Technol, 34 (2) 114-121

Algahtani, A.F. (2011). Evaluating the Effectiveness of the E-Learning Experience in Some Universities in Saudi Arabia from Male Students' Perceptions Doctoral dissertation Durham University. Retrieved from http://etheses.dur.ac.uk/3215/1/Abdullah'sThe sis.pdf

Al-Hariri, M., Al-Hattami, A. (2017). Impact of students' use of technology on their learning achievements in physiology courses at the University of Dammam, J. Taibah Univ. Med. Sci, 12 (1) 82-85. https://doi.org/10.1016/j.jtumed.2016.07.004

Allan, J., \& Lawless, N. (2005). Learning through online collaboration by SME staff: A scoping investigation into likely team-role stressors. Education and Training, 47, 653-664. https://doi.org/10.1108/00400910510633189

Anderson, Lorin W., David R. Krathwohl, and Benjamin Samuel Bloom. (2001). A Taxonomy for Learning, Teaching, and Assessing: A Revision of Bloom's Taxonomy of Educational Objectives Complete ed. New York: Longman.

Aristovnik, A., Tomazevic, N., Kerzic, D., Umek, L. (2017). The impact of demographic factors on selected aspects of e-learning in higher education, Int. J. Inf. Learn Technol, 34 (2) 114-121

Azhar, Djahir, B., \& Alfitri. (2015). Relationship of knowledge and ethics environment with attitudes and behaviors to protect the environment. Journal of Environmental Science. 13 (2) 36-41

Cabinet Office of Japan. (2019). Society 5.0. Retrieved from.

https://www8.cao.go.jp/cstp/english/society5_ 0/index.html

Chen X. D. (2013). An empirical study on the effect of PBL teaching model on critical thinking ability of non-English students. Journal of PLA University of Foreign Languages, 4, 68-72. http://doi.org/10.5539/elt.v11n4p15

Cheung, Y., \& Lee, T.Y. (2010). Improving social competence through character Education. Journal Evaluation and Program Planning, 33(3) 255-263. https://doi.org/10.1016/j.evalprogplan.2009.08. $\underline{006}$

Febrianawaty, Y., \& Ahmad, M. (2016). Development of Assessment Instruments Attitudes Towards The Environment Are Valid And Reliable for High School Students. Proceedings of the XII National Seminar on Biology Education. FKIP UNS 292-296.

Government of Japan. (2020). Abenomics. Retrieved from https://www.japan.go.jp/abenomics/index.htm 
Government of Japan. (2020). Innovation Japan. Retrieved from.

https://www.japan.go.jp/technology/innovatio $\mathrm{n} /$ index.html

Hubackova, S. (2015). History and perspectives of elearning, Procedia - Soc. Behav. Sci. 191 1187-1190. http://dx.doi.org/10.1016/j.sbspro.2015.04.594

Iswari, D., \& Suyud, U. (2017). Evaluation of The Implementation of The Adiwiyata Program for Form Environmental Care Behavior Among Students Science. Journal Environment. 15 (1) 35-41

Kerzic, D., Umek, L., Tomazevic, N., Aristovnik, A. (2018). Evaluating the impact of e-learning on students' perception of acquired competencies in a university hybrid learning environment. J. $e$ Learn. Knowl. Soc. 14(3) 65-76. http://dx.doi.org/10.20368/1971-8829/1440

Kimathi, F., Zhang, Y. (2019). Exploring the general extended technology acceptance model for elearning approach on student's usage intention on e-learning system in University of Dar es Salaam. Creativ. Educ 2151 (4771) 208-223. Retrieved from https://www.scirp.org/journal/paperinformati on.aspx?paperid $=90232$

King, F. J. (2011). Higher Order Thinking Skills. Center for Advancement of Learning and Assessment

Krathwohl, D. R. (2002). A revision of Bloom's taxonomy: An overview Theory into practice 41(4) 212-218. Retrieved from https://cmapspublic2.ihmc.us/rid=1Q2PTM7H L-26LTFBX-9YN8/Krathwohl\%202002.pdf

Krulik, S., \& Rudnick, J. A. (1999). Innovative Tasks to Improve Critical and Creative Thinking Skills. Developing Mathematical reasoning in Grades K12 138-145

Kuhlemeier, H., Hubb, B., \& Lagerweijg, N. (1999). Environmental Knowledge, Attitudes, and Behavior in Dutch Secondary Education. The journal of Environmental Education. 30(2), 4-14. https://doi.org/10.1080/00958969909601864

Kusuma, M. D., Rosidin, U., Abdurrahman, A., \& Suyatna, A. (2017). The Development of Higher Order Thinking Skill (HOTS) Instrument Assessment In Physics Study. IOSR Journal of Research \& Method in Education (IOSRJRME), 07(01), 26. https://doi.org/10.9790/73880701052632

Lake. (2010). Examining Trends in Adolescent Environmental Attitude, Beliefs and Behaviors Acroos 3 Decades. Journal Environmental Behavior. 42(1). 61-85. Retrieved from https://journals.sagepub.com/doi/abs/10.1177 $\not 0013916509335163$

Lei, L. H. (2011). The feasibility study of English PBL teaching model. Economic Research Journal, 29, 240-
241

Lin, M., Chen, H., Liu, K. (2017). A study of the effects of digital learning on learning motivation and learning outcome, Eurasia J. Math. Sci. Technol. Educ, $\quad 13 \quad$ (7) 3553-3564. https://doi.org/10.12973/eurasia.2017.00744a

Marc, J.R. (2002). Book review: e-learning strategies for delivering knowledge in the digital age, Internet High Educ, $5.185-188$. https://doi.org/10.1002/pfi.4140410512

Ministry of Environment. (2014). Environment Day Guideworld. KLH Republic of Indonesia: Jakarta.

Muhammad, A. D. (2013). Environmental management must be integrated. Media Environmental Communication Serasi Magazine Edition 2/2013 $\mathrm{KLH}$

Nelson, E.T. (2008). Effects of online problem-based learning on teachers' technology integration perceptions and planning. Pro Quest Digital Dissertations.

Norris, I. E., \& Juliet, U. D. (2016). Impact of environmental education on the knowledge and attitude of students towards the environment. International Journal of Environmnetal \& Science Education. 11(12). 5367-5375. Retrieved from https://files.eric.ed.gov/fulltext/EJ1115646.pdf

Oye, N.D., Salleh, M., Iahad, N.A. (2010). Holistic elearning in Nigerian higher education institutions. J. Comput. 2 (11) 20-26

Pane, M. M., \& Rina, P. (2015). The Significance of Environmental Contents in Character Education For Quality of Life. Journal Procedia Social and Behavioral Sciences. (222) 244-252. https://doi.org/10.1016/j.sbspro.2016.05.153

Ren, L. F. (2015). Application of the PBL teaching mode in the teaching of English writing. Reading and Writing Journal. 8(5) 128-129

Roffe, I. (2002). E-learning: engagement, enhancement and execution Qual. Assur. Educ 10 (1) 40-50. https://doi.org/10.1108/09684880210416102

Rojko, A. (2017). Industry 4.0 concept: background and overview.International Journal of Interactive Mobile Technologies (iJIM),11(5), 77-90. https://doi.org/10.3991/ijim.v11i5.7072

Salgues, B. (2018). Society 5.0 Industry of the Future, Technologies, Methods and Tools London: ISTE Ltd.

Sambrook, S. (2003). E-learning in small organizations. Educ. Train, 45(8-9), 506-516. https://doi.org/10.1108/00400910310508892

Saprudin, Sutarno, \&Liliasari. (2010). Developing Generic Science Skills of Prospective Teacher Through Offline And Online Interactive Multimedia In Physics Learning. Proceeedings of The $4^{\text {th }}$ International Conference on Teacher Education: UPI \& UPSI. 8-10 November 2010: 669-675. 
Saputra, H. (2016). Development of Education Quality Towards the Global Era: Strengthening the Quality of Learning by Implementing HOTS (High Order Thinking Skills). Bandung SMILE's Publishing

Saritepeci, M., \& Cakir, H. (2015). The effect of hybrid learning environments on student motivation and student engagement: A study on social studies course. Egitim ve Bilim, 40(177), 203-216. https:// doi.org/10.15390/eb.2015.2592

Schank, R.C. (2002). Designing world class e-learning, first ed: McGraw Hill New York.

Sekhon, M., Hartley, D. (2014). Basics of e-learning revisited. American Society for Training $\mathcal{E}$ Development: Alexandria VA.

Sholihin, N. (2019). Mengenal Society 5.0 Transformasi Kehidupan yang Dikembangkan. Retrieved from https:// www.timesindonesia.co.id/read/news/ 1...jepang

Song, J., \& Cheng, L. (2015). The PBL flipping model research of the college English teaching under the MOOC platform. Learning and Practice 5 135-140

Sukartono. (2018). Revolusi Industri 4.0 dan Dampaknya terhadap Pendidikan di Indonesia. Retrieved from:

http://pgsd.ums.ac.id/wpcontent/uploads/site s/73/2018/12/Materi-Sukartono.pdf. [Indonesian]

Suresh, M., Priya, V., Gayathri, R. (2018). Effect of elearning on academic performance of undergraduate students, Drug Invent Today, 10 (9) 1797-1800

Tresnawati, T., Hidayat, W., \& Rohaeti, E. (2017). Kemampuan Berpikir Kritis Matematis Dan Kepercayaan Diri Siswa SMA. Symmetry: Pasundan Journal of Research In Mathematics Learning And Education, 2(2), 39-45. https://doi.org/10.23969/symmetry.v2i2.616 [Indonesian]

Umek, L., Aristovnik, A., Tomazevic, N., Kerzic, D. (2015). Analysis of selected aspects of students' performance and satisfaction in a Moodle-based e-learning system environment. Eurasia J. Math.

Sci. Technol. Educ. 11(6). 1495-1505. https://doi.org/10.12973/eurasia.2015.1408a

Zhi, Y.B. (2009). Application of PBL in foreign language education in Chinese. Foreign Languages and Their Teaching, 7, 33-37. Retrieved from. http:/ / en.cnki.com.cn/Article_en/CJFDTOTALWYWJ200907012.htm 